\title{
MODEL MANAJEMEN \\ MADRASAH ALIYAH EFEKTIF \\ (Studi pada Tiga Madrasah Aliyah di Kudus)
}

\author{
Fatah Syukur \\ Universitas Islam Negeri (UIN) Walisongo Semarang \\ fsyukur@gmail.com
}

\begin{abstract}
This study aimed to find an effective management model madrasah, with essential elements of program planning, program implementation plans, monitoring and effective evaluation program for madrasah aliyah. This study used multiple case study design. Cases studied are the madrasah management models MAN 2 Kudus, MA-NU Banat Kudus and TBS$N U$ Kudus. The research findings indicated that; in the field of planning; Madrasab is able to formulate a collaboration program planning with stakeholders, in a comprehensive manner. In the implementation of the work plan; Principals responsibility is to manage the entire work program, while its implementation is being coordinated by Vice-Principals in accordance with their fields. In the field of monitoring and evaluation; Madrasah always formulates objective, responsible and sustainable monitoring and evaluation plan based on the national standard.
\end{abstract}

Keywords: Management, Madrasah Aliyah, Effective

\begin{abstract}
Abstrak
Tujuan dari penelitian ini adalah untuk menemukan model manajemen madrasah efektif, dengan unsur-unsur pokok perencanaan program, pelaksanaan rencana program, pengawasan, evaluasi program dan model manajemen madrasah efektif. Penelitian kualitatif ini menggunakan rancangan studi multi kasus. Kasusyang diteliti adalah model manajemen madrasah MAN 2 Kudus, MA NU Banat Kudus, dan MA NU TBS Kudus. Temuan penelitian ini menunjukkan bahwa; dalam bidang perencanaan; Madrasah mampu merumuskan perencanaan program bersama stakeholder, secara komprehensif. Dalam pelaksanaan rencana kerja; Kepala Madrasah bertanggung jawab terhadap semua program kerja, sedang pelaksanaannya dikoordinasikan oleh Wakil Kepala Madrasah sesuai dengan bidangnya. Dalam bidang pengawasan dan evaluasi; Madrasah selalu menyusun rencana pengawasan dan evaluasi secara obyektif, bertanggungjawab dan berkelanjutan yang didasarkan kepada standar nasional.
\end{abstract}

Kata Kunci: Manajemen, Madrasah Aliyah, Efektif

Permalink/DOI: http://dx.doi.org/10.18326/infsl3.v9i2.467-490 


\section{Pendahuluan}

Madrasah mempunyai misi penting yaitu mempersiapkan generasi muda umat Islam untuk ikut berperan dalam pembangunan umat dan bangsa di masa depan. Pentingnya misi lembaga ini disebabkan karena hampir seratus persen siswa yang belajar di lembaga pendidikan madrasah ini adalah anak-anak dari keluarga santri. Namun demikian kualitas lembaga yang mengemban misi penting ini, menurut Furchan (2004:38), mantan Direktur Perguruan Tinggi Agama Islam, amat memprihatinkan. Kualitas pendidikan di madrasah yang ada di luar pondok, terutama yang yayasan-nya kurang kuat sering berada di bawah standar, baik dilihat dari segi pendidikan agama maupun dari segi pendidikan umum.

Keberhasilan madrasah dalam menyiapkan anak didik dalam menghadapi tantangan masa depan yang lebih kompleks, akan menghasilkan lulusan yang akan menjadi pemimpin bangsa yang ikut menentukan arah perkembangan bangsa ini. Sebaliknya kegagalan madrasah dalam menyiapkan anak didik menghadapi tantangan masa depan akan menghasilkan lulusan-lulusan yang frustasi, tersisih, dan menjadi beban masyarakat. Di sinilah terdapat makna penting upaya peningkatan kualitas pengelolaan madrasah aliyah yang efektif. Madrasah Aliyah yang akan mengantarkan alumni ke perguruan tinggi harus menyiapkan siswa-siswinya dengan bekal ilmu pengetahuan dan teknologi, disamping bekal ilmu keagamaan sebagai ciri khas pendidikan di madrasah.

Berangkat dari pemikiran di atas, penulis meneliti tiga madrasah aliyah yang memiliki keunggulan prestasi akademik dan non akademik dengan pesantren sebagai basisnya, yakni Madrasah Aliyah Negeri 2 Kudus, Madrasah Aliyah NU Banat Kudus, dan Madrasah Aliyah NU TBS Kudus. Menurut hasil akreditasi Badan Akreditasi Pendidikan Sekolah/Madrasah (BAPS/M) Propinsi Jawa Tengah tahun 2008, ada empat madrasah aliyah di Kudus yang mendapatkan nilai akreditasi A, diantaranya adalah tiga madrasah aliyah tersebut, yakni MAN 2 Kudus (akreditasi A nilai 95), MA NU Banat Kudus (akreditasi A nilai 95), dan MA NU TBS (akreditasi A nilai 86). Fokus penelitian ini diarahkan pada perencanaan program, pelaksanaan program, pengawasan dan evaluasi 
berhubungan dengan: 1). Perencaan program madrasah aliyah efektif, 2) Pelaksanaan rencana program madrasah aliyah efektif, 3)Pengawasan dan evaluasi program madrasah aliyah efektif, 4) Model manajemen madrasah aliyah efektif.

\section{Kerangka Konseptual dan Alur Berfikir}

Refleksi empirik (Satori, 1995: 16) yang dibahas dalam satu diskusi tentang mutu pendidikan sampai pada kesepakatan bahwa mutu pendidikan (MP) di sekolah merupakan fungsi dari mutu input peserta didik yang ditunjukkan oleh potensi siswa (PS), mutu pengalaman belajar yang ditunjukkan oleh kemampuan profesional guru (KP), mutu penggunaan fasilitas belajar (FB), dan budaya sekolah (BS) yang merupakan refleksi mutu kepemimpinan kepala sekolah. Pernyataan tersebut dapat dirumuskan dalam formula sebagai berikut:

\section{MP = f (PS.KP.FB.BS)}

Potensi Siswa (PS) adalah kepemilikan kemampuan yang telah dianugerahkan oleh Allah SWT kepada setiap manusia. Dalam wacana psikologi pendidikan kemampuan tersebut dikenal sebagai natural or acquired talent yang dibedakan menjadi kemampuan umum (general aptitude) yang dinyatakan dalam ukuran IQ (Intelligent Quotient) dan kemampuan khusus yang biasa disebut bakat (special aptitude). Kemampuan profesional guru direfleksikan pada mutu pengalaman pembelajaran siswa yang berinteraksi dalam kondisi proses belajar mengajar. Kondisi ini sangat dipengaruhi oleh: (1)tingkat penguasaan guru terhadap bahan pelajaran dan penguasaan struktur konsep-konsep keilmuannya, (2)metode, pendekatan, gaya/seni dan prosedur mengajar, (3)pemanfaatan fasilitas belajar secara efektif dan efisien, (4)pemahaman guru terhadap karakteristik kelompok dan perorangan siswa, (5) kemampuan guru menciptakan dialog kreatif dan menciptakan lingkungan belajar yang menyenangkan, dan (6)kepribadian guru.

Atas dasar analisis tersebut, maka upaya untuk meningkatkan mutu pendidikan di sekolah harus disertai dengan upaya-upaya untuk meningkatkan kemampuan profesional dan memperbaiki 
kualitas kepribadian gurunya. Pada tingkat sekolah, upaya tersebut ditunjukkan dalam kegiatan-kegiatan berikut (Garmston and Wellman, 1995), yaitu: (1)interaksi kolegialitas di antara guru-guru, (2)pemahaman proses-proses kognitif dalam penyelenggaraan pengajaran, (3)penguasaan struktur pengetahuan mata pelajaran, (4)pemilikan pemahaman dan penghayatan terhadap nilai, keyakinan, dan standar, serta (5)keterampilan mengajar, dan (6) pengetahuan bagaimana siswa belajar.

Fasilitas belajar menyangkut ketersediaan hal-hal yang dapat memberikan kemudahan bagi perolehan pengalaman belajar yang efektif dan efisien. Fasilitas belajar yang sangat penting adalah laboratorium yang memenuhi syarat, bengkel kerja, perpustakaan, komputer, dan kondisi fisik lainnya yang secara langsung mempengaruhi kenyamanan belajar. Dari analisis sekolah efektif tersebut dapat simpulkan bahwa sekolah yang efektif adalah sekolah yang: (1) memiliki masukan siswa dengan potensi yang sesuai dengan tuntutan kurikulum, (2) dapat menyediakan layanan pembelajaran yang bermutu, (3) memiliki fasilitas sekolah yang menunjang efektivitas dan efesiensi kegiatan belajar mengajar, (4) memiliki kemampuan menciptakan budaya sekolah yang kondusif sebagai refleksi dari kinerja kepemimpinan profesional kepala sekolah.

Untuk melihat karateristik sekolah efektif, dapat diidentifikasi dari empat kelompok yaitu: (1)supporting inputs yang meliputi dukungan orang tua dan masyarakat, lingkungan belajar yang sehat, dukungan yang efektif dari sistem pendidikan, serta kelengkapan buku dan sumber belajar yang memadai; (2)enabling condition yang meliputi kepemimpinan yang efektif, tenaga guru yang kompeten, fleksibilitas dan otonomi serta waktu di sekolah yang lama; (3)school climate yang meliputi harapan siswa yang tinggi, sikap guru yang positif, keteraturan dan disiplin, kurikulum yang terorganisasi. Sistem reward dan insentif bagi siswa dan guru, serta tuntutan waktu belajar yang tinggi; dan (4)teaching-learning process yang meliputi strategi mengajar yang bervariasi, pekerjaan rumah yang sering, penilaian dan umpan balik yang sering, dan partisipasi (kehadiran, penyelesaian studi, kelanjutan studi) siswa. 


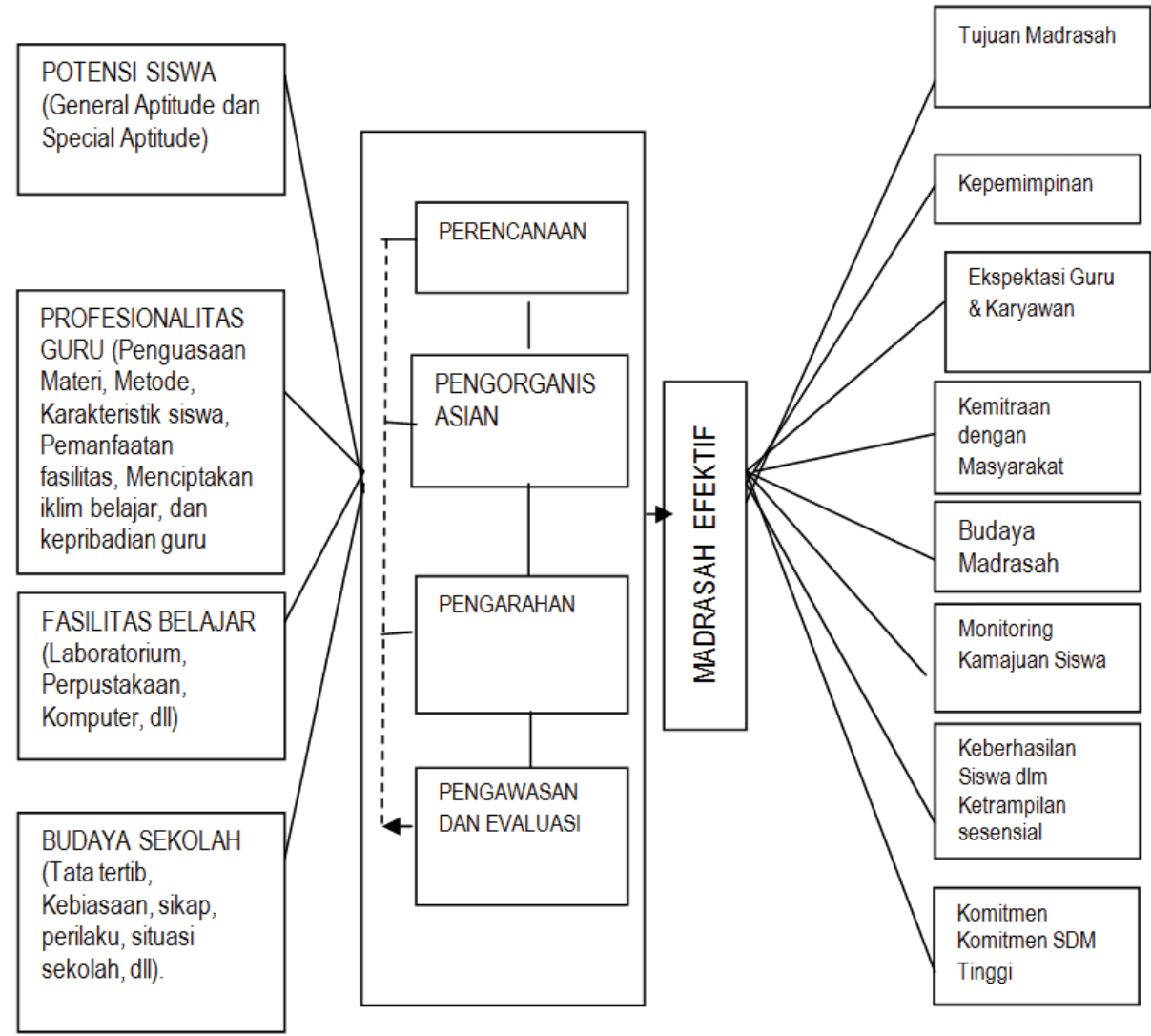

Gambar 1

Kerangka Berfikir Madrasah Aliyah Efektif

\section{Metode Penelitian}

Jenis Penelitian

Untuk menemukan model manajemen madrasah efektif, dengan unsur-unsur pokok yang harus ditemukan sesuai dengan butir-butir rumusan masalah dan tujuan penelitian, maka digunakan pendekatan penelitian kualitatif.

\section{Teknik Pengumpulan Data}

Dalam mengumpulkan data, peneliti memakai tiga teknik, yaitu wawancara mendalam, observasi partisipan dan non partisipan serta studi dokumentasi. 


\section{Teknik Analisis Data}

Teknik analisis data yang digunakan dalam penelitian ini adalah analisis data kualitatif, Aktivitas dalam analisis kualitatif dilakukan secara interaktif dan berlangsung secara terus menerus pada setiap tahapan penelitian sehingga sampai tuntas, dan datanya sampai jenuh. Aktivitas dalam analisis data, yaitu data reduction, data display, dan conclusion drawing/verification.

\section{Hasil Penelitian}

\section{Perencanaan Program Madrasab Efektif}

Sebuah perencanaan disusun melalui tahap merumuskan dengan melibatkan stakeholder madrasah, kemudian kepala madrasah menetapkan perencanaan program dan disyahkan oleh kepala kantor wilayah Kementerian Agama. Setelah disyahkan, tahap selanjutnya adalah mensosialisasikan perencanaan tersebut kepada semua warga madrasah. Dengan sosialisasi diharapkan tumbuh partisipasi yang tinggi dari semua stakeholder dalam mensukseskan perencanaan program yang sudah diputuskan.

Hoyle (1985) menyebutkan bahwa perencanaan pendidikan merupakan suatu proses untuk "get there from here", maju ke tempat tertentu yang lebih baik dari tempat sekarang. Setiap perubahan yang diinginkan, besar atau kecil, untuk mendapatkan hasil yang terbaik diperlukan suatu proses perencanaan.

Keberadaan visi dan misi dalam proses pembuatan perencanaan sangat penting. Sinamo (1998: 4) menegaskan bahwa "visi adalah apa yang didambakan organisasi untuk "dimiliki" atau diperoleh di masa depan (what do we want to have). Sedang misi adalah dambaan tentang kita ini akan "menjadi" apa di masa depan (what do we want to be). Agar efektif dan powerful, maka visi dan misi harus jelas, harmonis, dan kompatibel. Muhammad Gaffar (1994) berpendapat bahwa visi adalah daya pandang yang jauh, mendalam dan meluas, merupakan daya fikir abstrak yang memiliki kekuatan amat dahsyat dan dapat menerobos segala batas-batas fisik, waktu dan tempat. Visi adalah kunci energi manusia, kunci atribut pemimpin dan pembuat kebijakan. 
Terwujudnya visi bergantung kepada usaha yang dilakukan sendiri oleh organisasi dan hal-hal yang terjadi di luar organisasi. Visi dan misi yang kuat sangat diperlukan demi kelangsungan hidup organisasi. Karena itu visi dan misi harus cocok dengan sejarah, budaya, semangat, dan nilai-nilai organisasi. Visi dijadikan sebagai pedoman dalam melaksanakan program kerja sebuah organisasi. Semua warga madrasah harus mengetahui dan memahami visi madrasahnya. Oleh karena itu visi harus disosialisasikan seluas luasnya kepada stakeholder madrasah. Dari diskripsi proposisi tersebut, penulis membuat diagram model perencanaan program madrasah efektif sebagai berikut:

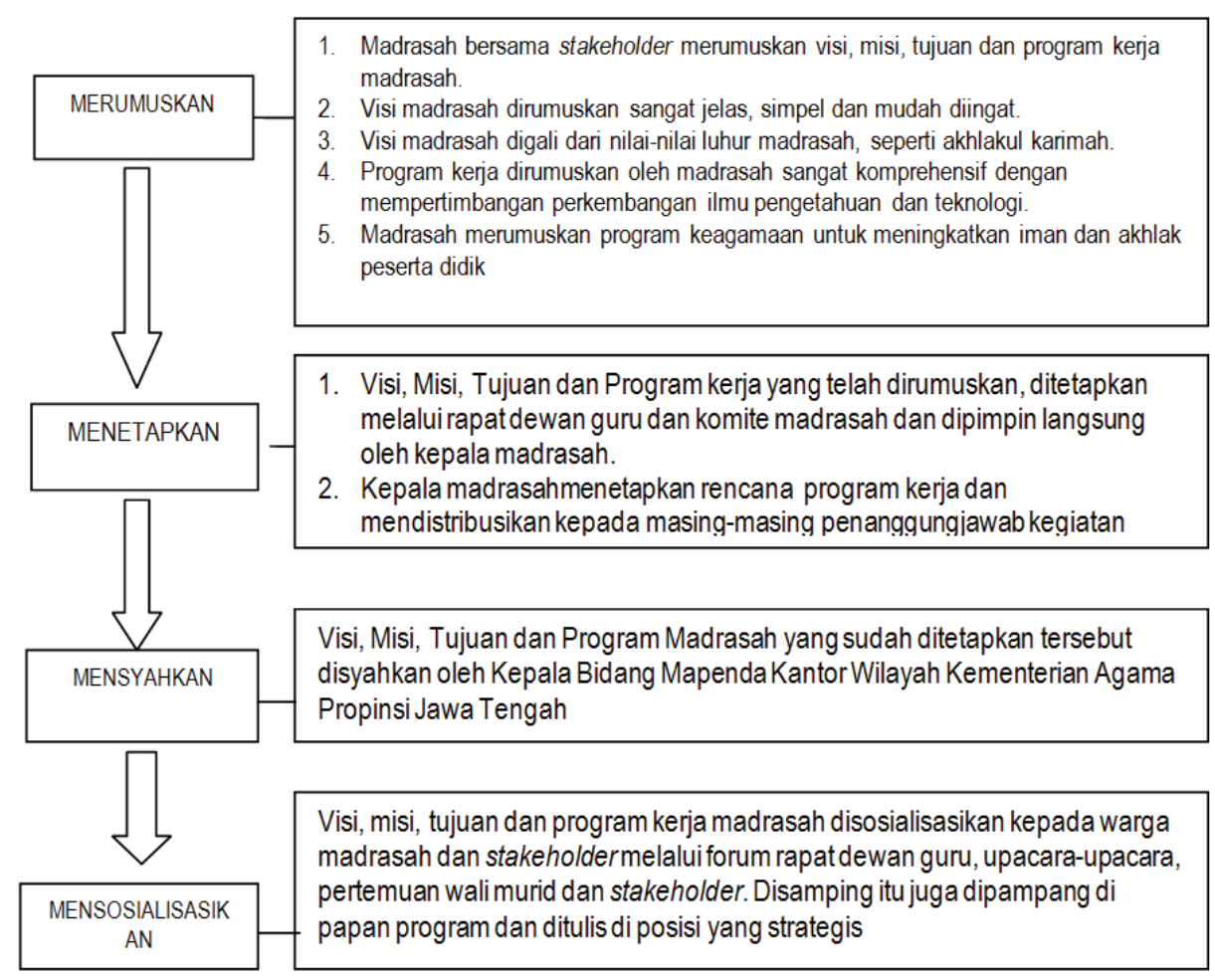

\section{Gambar: 2. \\ Model Perencanaan Madrasah Efektif}


Dari pembahasan di atas menunjukkan bahwa dalam menyusun sebuah perencanaan program, keterlibatan semua komponen organisasi sangat diperlukan agar perencanaan tersebut dapat mencakup semua kepentingan dan memperhatikan semua sektor. Pihak yang dimaksud adalah pimpinan madrasah, dewan guru, dan komite madrasah. Perencanaan yang dihasilkan dari ketiga pihak tersebut diharapkan menjadi hasil perencanaan yang ideal. Penulis menggambarkan model perencanaan tersebut sebagaimana gambar di bawah ini, yang penulis sebut sebagai model tripartet.

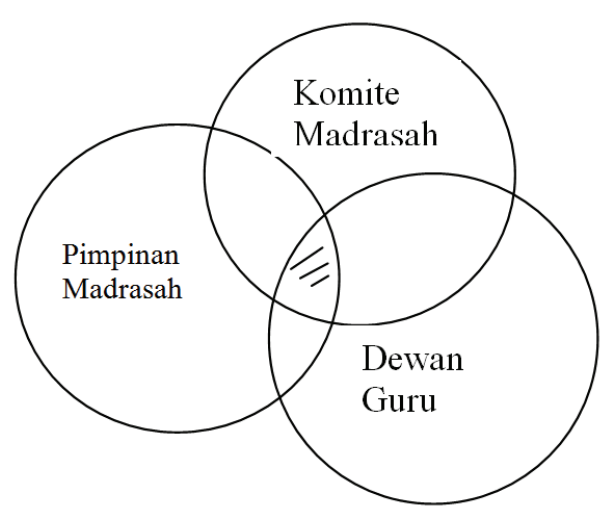

Gambar: 3.

Model Tripartet Perencanaan Program Madrasah Efektif

Dari gambar tersebut terlihat ada wilayah perencanaan yang menyangkut satu pihak, ada yang menyangkut dua pihak, dan ada yang menyangkut tiga pihak. Masing-masing kepentingan tersebut harus didiskusikan dan disepakati bersama, sehingga menghasilkan perencanaan program yang disepakati bersama. Perencanaan yang sudah disepakati tersebut diharapkan menjadi komitmen bersama dan mendapatkan dukungan dari semua stakeholder madrasah.

\section{Pelaksanaan Rencana Kerja Madrasab Efektif}

Untuk melaksanakan program ada tiga bagian penting yang perlu mendapatkan perhatian, yakni pedoman kerja, organisasi pelaksana, dan pelaksanaan kegiatan. Pedoman kerja merupakan acuan penyelenggaraan program agar sesuai dengan rencana kerja 
yang sudah ditetapkan. Dalam melaksanakan rencana program, para pelaksana program atau organisasi pelaksana harus memahami dan menjadikan pedoman kerja sebagai pemandu pelaksanaan program.

Dalam melaksanakan program diperlukan keteladanan, kepala madrasah mampu memberikan keteladanan kepada para guru, karyawan dan para sisiwa, serta mampu menumbuhkan inovasi-inovasi dalam pembelajaran dan manajemen madrasah. Ellis (1986) dalam penelitiannya menemukan bahwa sekolah jarang sekali efektif, kalau kepala sekolahnya bukan merupakan seorang pemimpin instruksional yang cakap. Pimpinan sekolah yang kurang cakap dan kreatif, akan menjadi tidak efektif. Williams (1986) yang merujuk penemuan Weber, menunjukkan bahwa sekolah-sekolah yang berhasil, mempunyai kepala sekolah dengan kepemimpinan instruksional yang kuat. Dari kepemimpinan yang kuat tersebut, tercipta harapan-harapan yang tinggi, iklim belajar yang teratur, dan penekanan yang kuat pada membaca. Pesan yang kiranya hendak dibawa oleh Williams tentang sekolah yang efektif adalah: "sekolah yang dapat membuat perbedaan" dalam keberhasilan pendidikan semua anak.

Penelitian Donovan pada tahun 1982 (dalam Batsis, 1987), menyimpulkan, bahwa di sekolah-sekolah efektif, terdapat harapan-harapan guru terhadap siswa yang sangat jelas. Harapan itu senantiasa dikemukakan dalam kehidupan sehari-hari pada kesempatan pertama yang memungkinkan. Akhirnya semua pihak berusaha untuk mencapai harapan-harapan tersebut.

Sehubungan dengan berbagai penelitian tentang sekolah efektif, Jackson (1983) menemukan perbedaan-perbedaan antara sekolah efektif dan tidak efektif di Washington DC. Perbedaan yang dimaksud menyangkut: (1) gaya kepemimpinan kepala sekolah dan dukungan guru; (2) peran guru dalam pengajaran; dan (3) pengembangan staf. Penelitian ini menekankan akan peran kepala sekolah, dan tenaga administrasi dalam upaya meningkatkan prestasi akademik siswa.

Sejalan dengan penelitian di atas, Seuburu dan Sudlow (1987), berdasarkan penelitian dan percobaannya menyimpulkan bahwa pengembangan staf, khususnya guru, merupakan kunci bagi suksesnya pelaksanaan proyek-proyek yang efektif. Sedangkan Gezi 
(1986), dalam penelitiannya menyatakan bahwa kepemimpinan kepala sekolah merupakan faktor yang menjadikan sekolah sampel menjadi efektif. Menurut Brookover (1982), kepala sekolah, guru dan karyawan lainnya, siswa dan orang tua, merupakan faktor utama yang sangat berpengaruh terhadap iklim belajar di sekolah. Mereka merupakan agen dalam mengembangkan iklim belajar tersebut.

Dari pembahasan di atas menunjukkan bahwa dalam pelaksanaan program, keterlibatan semua komponen organisasi sangat diperlukan agar pelaksanaan program tersebut dapat berjalan lancar dan berhasil baik. Pihak yang dimaksud adalah pimpinan madrasah, dewan guru, dan peserta didik. Penulis menggambarkan model pelaksanaan program tersebut sebagaimana gambar di bawah ini, yang penulis sebut sebagai model tripartet.

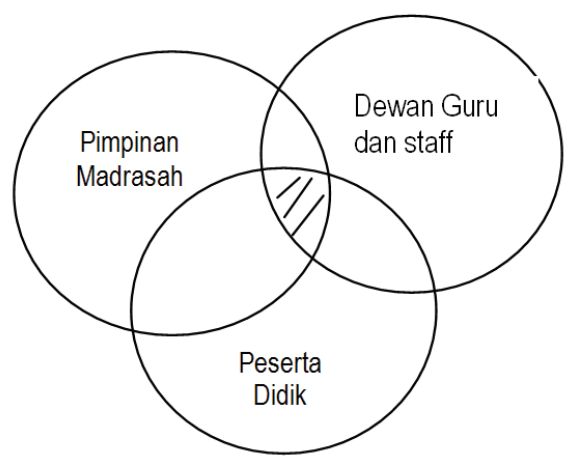

Gambar: 4.

\section{Model Tripartet Pelaksanaan Program Madrasah Efektif}

Untuk menciptakan madrasah efektif, keseluruhan karakteristik harus terlihat dan berfungsi setidak-tidaknya pada tingkatan tertentu, sehingga pengamat dari luarpun dengan mudah dapat mengakui kebenarannya. Supaya madrasah efektif dapat tercipta secara langgeng, perlu dijaga kelestarian keberadaan keefektifan karakteristik-karakterisik tersebut. Dalam pengelolaan di madrasah, fokus manajemen berbasis madrasah (MBM) dengan didasarkan kepada prinsip mutu, efektivitas, efisiensi dan akuntabilitas, memenuhi standar pendidikan nasional dan standar akreditasi. Dengan fokus inilah, madarasah akan dapat meningkatkan mutu pendidikan sebagaimana yang diharapkan oleh para stakebolder. 
Keberhasilan MBM salah satunya adalah adanya dukungan orang tua, berupa ide, gagasan, uang, material, tenaga dan sebagainya. Dukungan orang tua akan muncul manakala madrasah memiliki rencana dan program kegiatan pendidikan yang dapat memenuhi kebutuhan orang tua, yaitu mewujudkan peserta didiknya sebagai lulusan yang bermutu. Rencana dan program kegiatan pendidikan tersebut dilaksanakan dengan penuh tanggungjawab, efektif dan efisien, dengan penggunaan anggaran yang transparan, akuntabel, keadilan dan pemerataan. Madrasah berani terbuka untuk dimonitoring dan dievaluasi atau diaudit dalam pelaksanaan kegiatan dan penggunaan anggaran. Jika hal ini semua dapat diwujudkan oleh madrasah, maka dukungan orang tua dalam mewujudkan pendidikan yang bermutu di madrasah akan terwujud. Modal sosial atau sosial capital ini sangat penting agar madrasah selalu mendapatkan dukungan dari para stakeholder.

Salah satu ukuran mutu pendidikan adalah hasil akademik. Hasil akademik berupa prestasi nilai evaluasi belajar siswa, baik kemampuan kognitif, afektif, maupun psikomotoriknya. Hasil akademik baik adalah yang mencapai di atas tuntutan minimal nilai ujian nasional, yaitu di atas 6,01 untuk nilai Bahasa Indonesia, Bahasa Inggris dan Matematika. Untuk mencapai hasil tersebut, penggunaan waktu harus efektif. Semua waktu efektif untuk setiap jamnya minimal 45 menit digunakan oleh madrasah untuk proses kegiatan pembelajaran dengan baik dan menambah waktu untuk beberapa mata pelajaran tertentu yang memerlukan pendalaman atau remedial teaching, serta tidak terjadi pengorbanan waktu efektif belajar untuk kepentingan kegiatan kokurikuler apalagi untuk kegiatan ekstra kurikuler.

Madrasah efektif adalah madrasah yang selalu meningkatkan mutu kinerjanya dan mutu hasil penyelenggaraan pendidikan yang dilaksanakan, baik berupa prestasi akademik maupun prestasi non akademiknya. Produktivitas madrasah tercapai bila ada efisiensi dan peningkatan kualitas. Efisiensi yaitu penyelenggaraan pendidikan yang dilaksanakan oleh madrasah, jika dibandingkan antara input (masukan) dengan output (keluaran) atau hasil baik kinerja maupun prestasi siswa lebih besar dibandingkan dengan pengorbanan atau input (masukan) nya. Madrasah yang efektif melaksanakan proses 
penyelenggaraan atau layanan jasa pendidikan kepada masyarakat pelanggannya dengan kinerja tinggi dan menghasilkan lulusan atau output (keluaran) pendidikan yang bermutu, yaitu sesuai atau melebihi harapan, kebutuhan dan keinginan masyarakat dan dunia usaha. Madrasah yang efektif mengalami pertumbuhan kualitas yang meningkat dari tahun ke tahun, baik peningkatan kualitas input (masukan), peningkatan kualitas proses atau tansformation maupun kualitas lulusan atau output (keluaran) pendidikan.

Untuk mencapai madrasah yang efektif, motivasi dan semangat merupakan faktor yang penting. Motivasi, merupakan dorongan bagi seseorang untuk melakukan suatu pekerjaan atau kegiatan. Para siswa membutuhkan motivasi dari guru, dari orang tua dan motivasi dari dalam dirinya, agar mereka mau mengikuti proses belajar dengan baik. Guru dan staff/karyawan juga membutuhkan motivasi dari pimpinan atau kepala madrasah, agar mereka mau memberikan sumbangsih dengan baik, baik tenaga, waktu maupun pikirannya untuk mewujudkan tujuan madrasah. Untuk mewujudkan guru dan staff/karyawan yang termotivasi dan mau menjalankan tugas dengan baik, maka sesuai dengan teori Maslow, mereka harus dipenuhi kebutuhan fisiologisnya, rasa amannya, sosialnya, harga dirinya dan keberadaannya. Dengan motivasi yang tinggi, baik para guru, staff/ karyawan dan peserta didik, maka akan tercapai penyelenggaraan pendidikan yang baik, sehingga tercapailah madrasah yang efektif.

Dari diskripsi proposisi tersebut, penulis membuat diagram model pelaksanaan rencana kerja madrasah efektif sebagai berikut: 


\section{MODEL PELAKSANAAN PROGRAM KERJA MADRASAH EFEKTIF}

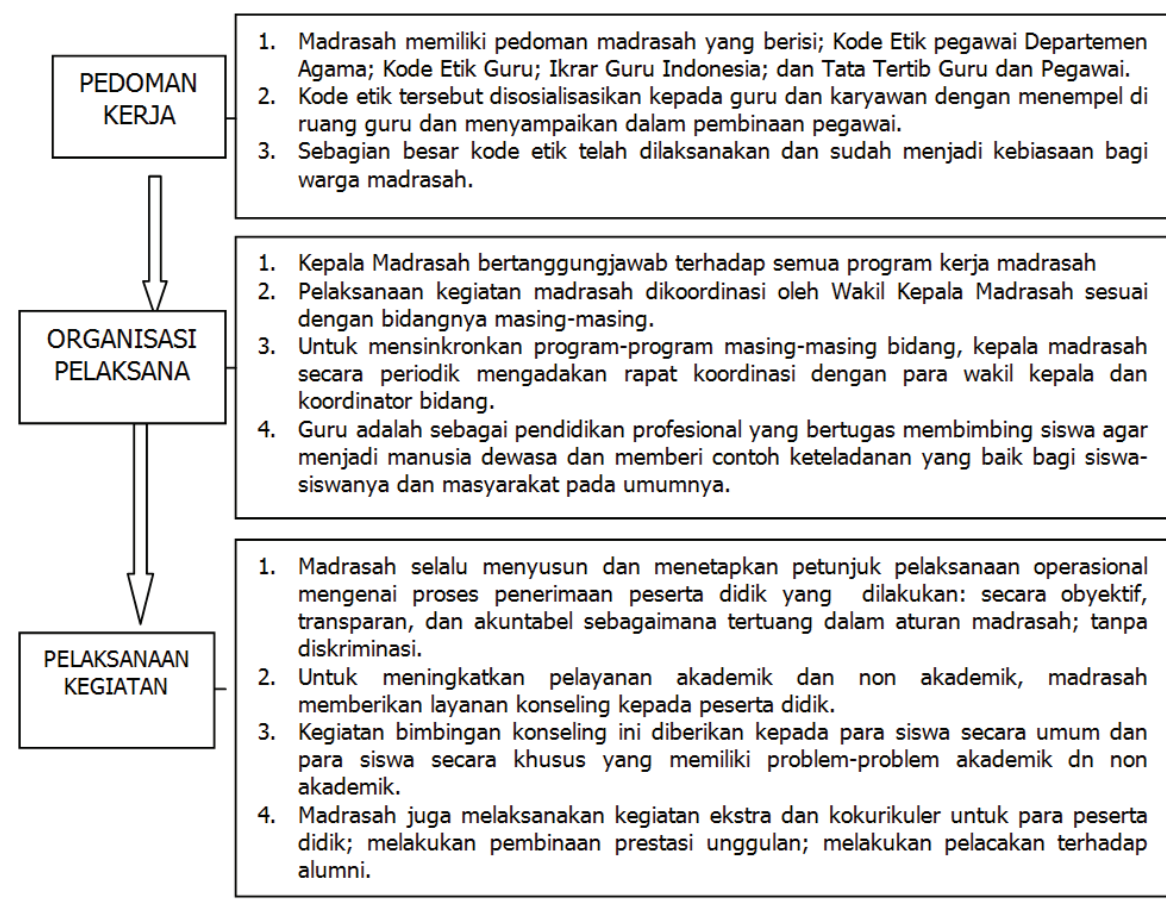

Gambar: 5.

Model Pelaksanaan Program Madrasah Efektif

\section{Pengawasan dan Evaluasi Madrasah Efektif}

Croghan (1983), mengartikan monitoring atau pemantauan, sebagai proses pemerolehan informasi tentang masalah. Informasi yang diperoleh, baik yang formal maupun yang tidak formal, digunakan untuk memecahkan masalah. Snyder (1986) mencatat, bahwa pemantauan bisa merupakan inspeksi, suatu fungsi kontrol yang diperlukan untuk menghasilkan produk yang dikehendaki, yang dapat digunakan untuk memodifikasi pengajaran. Inspeksi tersebut bisa merupakan kegiatan yang telah direncanakan waktunya maupun tidak, dan diberitahukan kepada guru maupun tidak.

Menurut Rutherford (1985), pemantauan merupakan suatu aktivitas yang dilakukan kepala sekolah dalam cara yang 
terbatas dan supervisial, seringkali hanya sebatas yang diinginkan sekolah. Pernyataan ini menekankan bahwa pelaku pemantauan adalah kepala sekolah, dalam bentuk kontrol, dan dilakukan sesuai dengan kebutuhan saja. Menurut ESCN (1987), prosedur pemantauan terhadap siswa ini harus ditetapkan secara jelas. Hasil tes, laporan nilai, catatan kehadiran dan tolak ukur lain terhadap performansi siswa dikomunikasikan kepada semua yang membantu mengembangkan alternatif-alternatif tindakan.

Menurut Williams (1986), di sekolah efektif, kepala sekolahnya melakukan pemantauan terhadap alokasi dan penggunaan waktu. Kemajuan siswa mendapat perhatian sepenuhnya. Guru melaporkan kemajuan siswa kepada kepala sekolah yang bersangkutan dan orang tua murid. Modifikasi pengajaran dilakukan bila dipandang perlu, sebagai tindak lanjut dari analisis data. Suatu hal yang harus benarbenar dijaga adalah terdapatnya kesesuaian antara kurikulum, materi yang diajarkan, dan tes yang digunakan untuk mengukur prestasi siswa.

Dari pembahasan di atas menunjukkan bahwa dalam pengawasan dan evaluasi, keterlibatan semua komponen organisasi sangat diperlukan agar pelaksanaan program tersebut dapat berjalan lancar dan berhasil baik. Pihak yang dimaksud adalah pengawas madrasah, pimpinan madrasah, dan dewan guru. Penulis menggambarkan model pengawasan dan evaluasi program tersebut sebagaimana gambar di bawah ini, yang penulis sebut sebagai model tripartet.

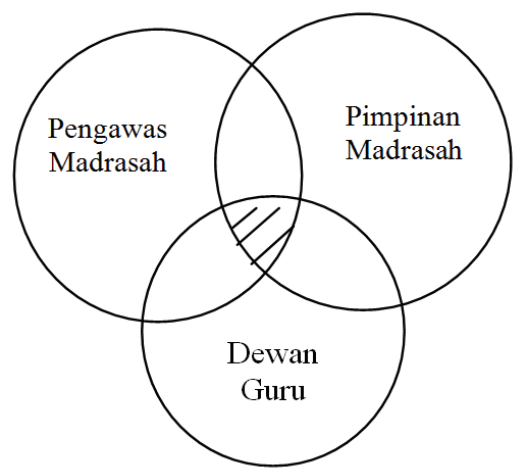

\section{Gambar: 6}

Model Tripartet Pengawasan dan Evaluasi Madrasah Efektif 


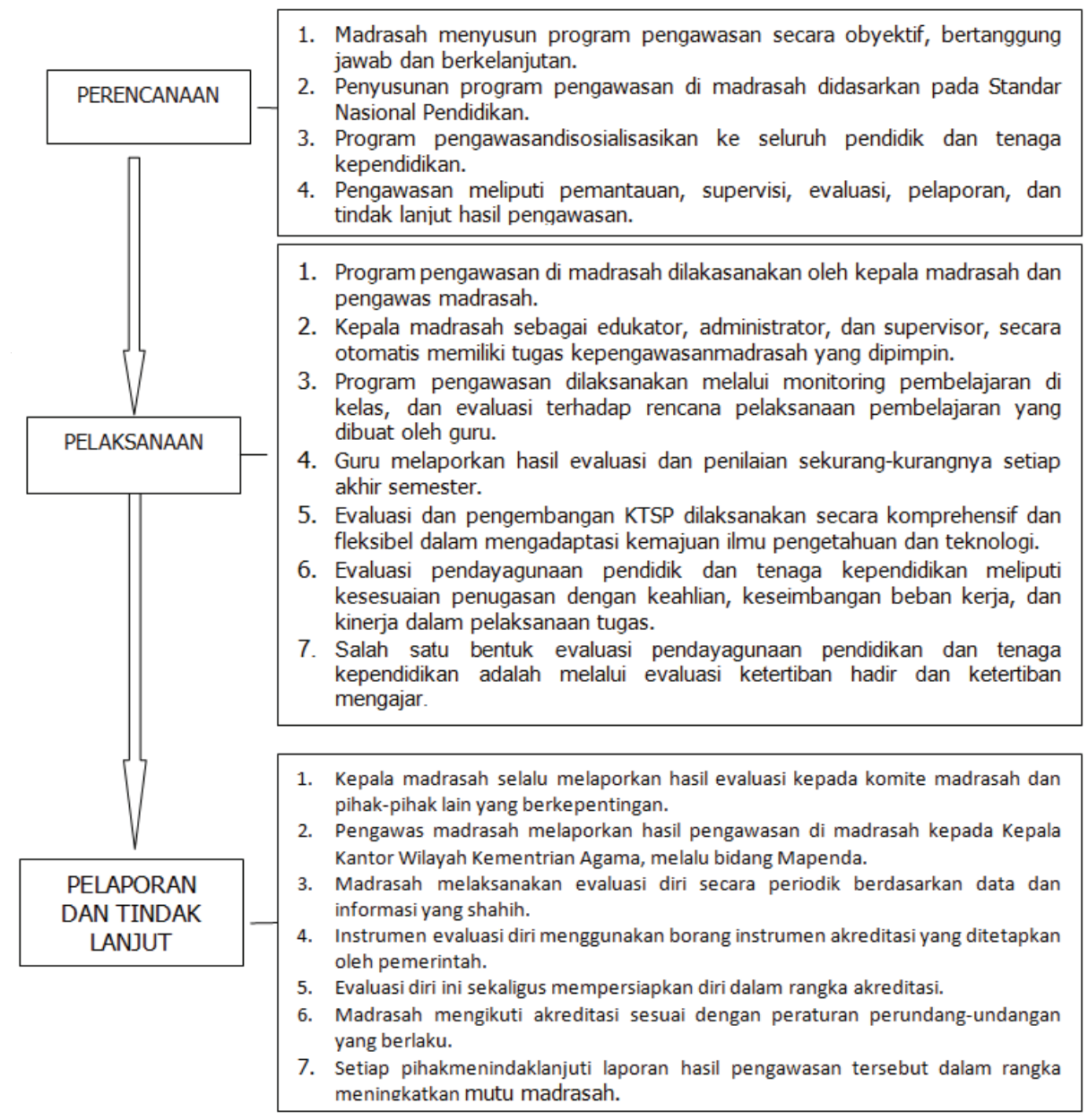

\section{Gambar: 7}

\section{Model Pengawasan dan Evaluasi Madasah Aliyah Efektif}

\section{Model Manajemen Madrasah Efektif}

Efektifitas merupakan suatu dimensi tujuan manajemen yang berfokus pada hasil, sasaran, dan target yang diharapkan. Dalam pengelolaan madrasah, peran kepala madrasah sangat menonjol. Keberadaan kepala madrasah yang baik, sangat besar sumbangannya terhadap madrasah efektif. Standfield dkk. (1987), berdasarkan hasil penelitian yang dilakukan selama 20 bulan, menggambarkan 
sekolah Garvin, Missouri, ia mengamati perilaku kepemimpinan kepala sekolahnya. Dari perspektif pola sekolah yang efektif kepala sekolah dipandang sebagai "ksatria" yang menyelamatkan anakanak dengan jalan memberikan pendidikan yang efektif. Ketika tokoh pendidikan ini baru tiba di sekolah tersebut, dijumpainya prestasi siswa yang rendah, disiplin yang tak terwujud, dan moral staf yang kurang baik.

Untuk memperbaiki keadaan yang demikian itu, kepala sekolah mengadakan pendekatan terhadap perbaikan pengajaran dalam empat aspek: disiplin, prestasi, sikap dan kepribadian. Semua aspek tersebut ditumbuhkan dengan berdasarkan pada harapan-harapan yang tinggi, tercipta suasana emosi yang positif, elaksanaan supervisi yang obyektif, dan penggunaan teknik-teknik kepemimpinan yang sesuai oleh kepala sekolah. Kondisi yang demikian terlihat di madrasah yang penulis teliti. Peran kepala madrasah sangat menentukan terhadap efektifitas perencanaan, pelaksanaan program kerja, serta pengawasan dan evaluasi. Dalam menggerakkan dewan guru dan staf madrasah, kepala madrasah melaksanakan dengan cara persuasif dan dengan memberi contoh/ keteladanan yang baik.

Peran guru juga sangat penting dalam kegiatan madrasah. Guru merupakan ujung tombak kegiatan madrasah, karena berhadapan langsung dengan siswa. Keberhasilan siswa sangat erat hubungannya dengan penampilan guru dalam mengelola proses belajar mengajar di depan kelas. Oleh karena itu hubungan antara guru dan siswa harus akrab, bersahabat, dan tidak menakutkan. Suasana belajar di dalam kelas harus diciptakan sebaik mungkin. Penelitian Donavon tahn 1982 (dalam Batsis, 1987), menyimpulkan, bahwa sekolahsekolah efektif, terdapat harapan-harapan guru terhadap siswa yang sangat jelas. Harapan itu senantiasa dikemukakan dalam kehidupan sehari-hari pada kesempatan pertama yang memungkinkan. Akhirnya semua pihak berusaha untuk mencapai harapan-harapan tersebut.

Kepemimpinan merupakan satu aspek penting dalam sistem sekolah/madrasah. Hampir semua pakar sekolah efektif mengeksplisitkan kepemimpinan sebagai ciri penting sebagai 
sekolah efektif, seperti Scheerens (1992) menyatakan bahwa sekolah efektif memiliki kepemimpinan yang kuat, Mackenzie (1992) mengidentifikasikan tiga pendidikan efektif dan kepemimpinan menjadi nomor urut pertama, Edmons (1979) menyebutkan bahwa ada lima karakteristik sekolah efektif, salah satunya adalah kepemimpinan dan perhatian kepala sekolah terhadap kualitas pengajaran, dan Heneveld (1992) berpendapat bahwa kepemimpinan yang efektif menjadi ciri sekolah efektif.

Penulis menggambarkan model manajemen madrasah yang efektif adalah sebagaimana dalam gambar berikut ini:

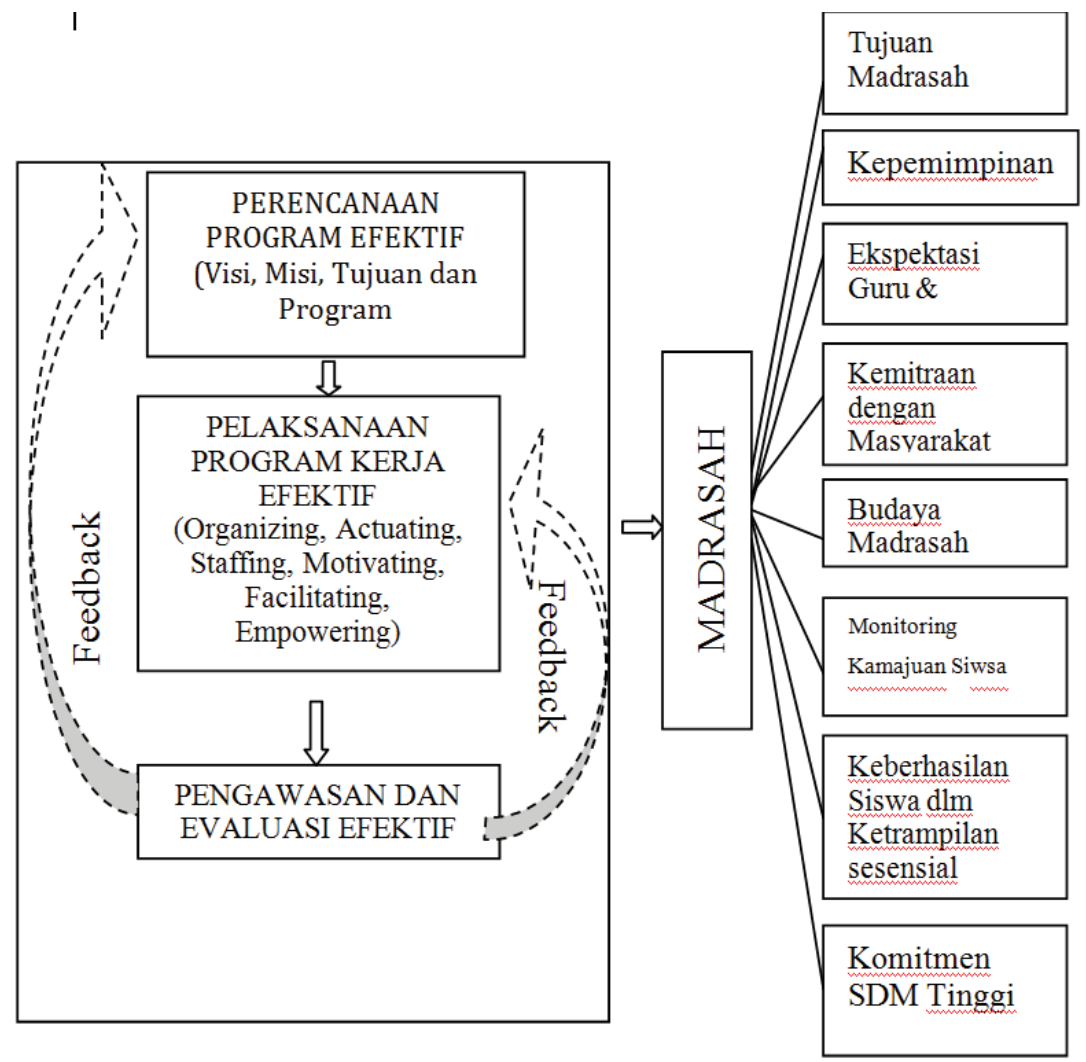

Gambar: 8. Model Manajemen Madrasah Efektif 


\section{Kesimpulan}

Berdasarkan fokus penelitian, paparan data dan temuan penelitian, analisis lintas kasus serta pembahasan, maka secara rinci hasil temuan penelitian dapat disimpulkan sebagai berikut: Model manajemen madrasah efektif adalah madrasah yang melaksanakan perencanaan program secara efektif, melaksanakan rencana kerja secara efektif, pengawasan dan evaluasi secara efektif dan akhirnya membentuk madrasah yang efektif. Ciri-ciri madrasah efektif yang ditemukan dalam penelitian ini meliputi; 1) Madrasah memiliki tujuan madrasahdigali dari internalisasi nilai-nilai luhur dan dinyatakan secara jelas, dipahami oleh siswa, guru, dan staf dan selalu digunakan untuk pengambilan keputusan. 2) Kurikulum madrasah disusun berdasarkan standar isi, dengan tambahan muatan lokal keagamaan (memakai kitab kuning), ilmu falaq (penanggalan), metodologi pembelajaran dan praktek pengalaman mengajar. Dalam pembelajaran sudah memanfaatkan multi media. 3) Kepala Madrasah: Selalu bersikap responsif kepada guru, staf, siswa, orang tua dan masyarakat. Kepemimpinannya selalu terfokus pada pembelajaran, dan mampu memberi teladan dalam pembinaan siswa. Selalu membangun komunikasi secara positif dengan orang tua, memelihara jaminan dukungan orang tua dan bekerjasama dengan orang tua dan masyarakat.Selalumenunjukkan komitmen dalam mendukung program keterampilan esensial. 4) Iklim madrasah tercipta secara kondusif dan religius. Lingkungan madrasah selalu rapi, bersih, dan aman secara fisik, dan dipelihara secara baik sehingga mendorong motivasi untuk belajar dan berprestasi. 5) Guru selalu memberi siswa tugas yang tepat, memberi umpan balik secara cepat (segera), memiliki kemampuan berpartisipasi di kelas secara optimal dan memberikan penilaian hasil belajar dari berbagai segi. Guru dan staf yakin bahwa semua siswa bisa belajar dan berprestasi, menekankan pada hasil akademis dan non akademis. 6) Siswa selalu mentaati aturan madrasah, menjalankan tugas/ kewajiban tepat waktu, melakukan yang terbaik untuk mencapai hasil belajar yang optimal, baik yang bersifat akademis maupun nonakademis, 7) Madrasah selalu memberi penghargaan kepada siswa yang berprestasi, memberi penguatan terhadap perilaku positif siswa. 


\section{Daftar Pustaka}

Brannen. Julia. 2002. Memadu Metode Penelitian Kualitatif \& Kuantitatif. Yogyakarta: Pustaka Pelajar.

Brookover, Wilbur B. 1982. Creating Effective Schools: An in Service Program for Enhancing School Learning Climate and Achievement. Florida: Learning Publications, Inc.

Bruce Hyland Merle Yost. 1994. Reflections for Managers Renungan Para Manajer (terj). Jakarta: Gramedia.

Bungin, Burhan. 2003. Analisis Data Penelitian Kualitatif. Jakarta: Raja Grafindo

Croghan, John H. 1983. Identivication of Competencies of High Performing Principles in Florida. Florida: FCEM.

Dhofier, Zamakhsyari. 1985. Tradisi Pesantren. Jakarta: LP3ES. . 1996. Kebijakan Departemen Agama dari Masa ke Masa Dalam kurun Setengah Abad. Jakarta: Badan Litbang Agama Departemen Agama RI.

E. Mulyasa. 2003. Menjadi Kepala Sekolah Profesional dalam Konteks Menyukseskan MBS dan KBK. Bandung: PT. Remaja Rosda Karya.

. 2005. Pedoman Manajemen Berbasis Madrasah. Jakarta: Direktorat Jederal Kelembagaan Agama Islam Depag RI.

Edmonds, Roland. 1979. "Effective School for the Urban Poor" Educational Leadership, 15-24 October 1979.

Effective School Consortia Network. 1987. Effective School Characteristics. Albany: ESCN.

Ekosusilo, Madyo. 2003. Supervisi Pengajaran Dalam Latar Budaya Jawa. Sukoharjo: Univet Bantara Press. 
2003. Sekolah Unggul Berbasis Nilai. Sukoharjo: Univet Bantara Press.

Fatah. Nanang.1999. Landasan Manajemen Pendidikan. Bandung: PT Remaja Rosdakarya.

Frederick, Judith J. 1987. Measuring School Efectiveness: Guidelines for Educational Practitioners. New York: ERIC, Princenton.

Furchan, Arief. 2004. Transformasi Pendidikan Islam di Indonesia, Yogyakarta: Gama Media.

Gaffar, M.F. 1994. Visi: Suatu Inovasi dalam Proses Manajemen Stratejik Perguruan Tinggi. Pidato Pengukuhan Guru Besar. Bandung: IKIP Bandung.

George R. Terry dan Leslie W. Rue. 2003. Dasar-dasar Manajemen (terj). Jakarta: Bumi Aksara.

Harbison, F., \& C. Meyrs. 1964. Education, Main Power and Economic Growth. New York: McGraw-Hill Book Company.

Hax. Arnoldo C. and Majluf. Nocolas S. 1996. The Strategy Concept and Process a Pracmatic Approach. Precentice Hall: Upper Saddle River. Ner Jersy.

Hecht. Maurice R. 1980. What Happens in Management.New York: AMACOM.

Hodge, B,J., \& Anthony. 1988. Organizational Theory. Boston, Mass-cusetts: Allyn and Bacon Inc.

Hoyle, John R. 1985. Skills for Successful School Leader. Arlington Virginia: Smerican of School Administration, Publishers.

J. Supranto. 2001 Pengukuran Tingkat Kepuasan Pelanggan. Jakarta: Rineka Cipta.

James H. McMillan. Sally Schumacher. 2001. Research in Education a Conceptual Introduction. New York: Longman. 
John W. Best. 1981. Research in Education. London: Prentice-Hall International.

Komaroiah, Aan dan Cepi Triatna. 2005. Visionary Leadership Menuju Sekolah Efektif. Jakarta: Bumi Aksara.

Kritek, William J. 1986. School Culture and School Improvement. San Francisco: Amercian Educational Research Association.

Lincoln, Y.S. \& Guba, E.G. 1985. Naturalistic Inquiry. Beverly Hill: Sage Publication Inc.

Malik, Ghulam Farid. 2000. Pedoman Manajemen Madrasah. Yogyakarta: Basic Education Project (BEP) Depag RI bekerjasama dengan Forum Kajian Budaya dan Agama (FKBA).

Mastuhu. 1994. Dinamika Sistem Pendidikan Pesantren. Jakarta: INIS.

Mas'ud. Abdurrahman. 1998. Why the Pesantren in Indonesia Remains Unique and Stronger. College of Islamic Studies PSU Pattani: Paper 25-28 June 1998.

Moedjiarto. 2001. Sekolah Unggul. Jakarta: Duta Graha Pustaka.

Moeljono, Djkosantoso. 2003. Beyond Leadership. Jakarta: PT elex Media Komputindo.

Muhadjir.Noeng. 1996. Metodologi Penelitian Kualitatif. Yogyakarta: Rakesarasin.

Muhtarom. 2005. Reproduksi Ulama di Era Globalisasi. Yogyakarta: Pustaka Pelajar.

Mulyana.Rohmat. 2004. Mengartikulasikan Pendidikan Nilai. Bandung: Alfabeta.

Musa, Ibrahim. 2001. Otonomi Penyelenggaraan Pendidikan Dasar dan Menengah. dalam Membangun Masyarakat Pendidikan. Jakarta: INSEP berkerjasama dengan BEP 
Depag RI.

Patricia Patton. 2002. EQ Ketrampilan Kepemimpinan. Jakarta: Mitra Media.

Peterson, M.W. (ed). 1987. Organization and Governance in Higher Education. Lexington, Massachusetts: Ginn Press.

Pitts Robert. A. and Lei. David. 1996. Strategic Management. Building and Sustaining Competitive Advantage. New York: West Publishing Company.

R. Edward Freeman. 1985. Manajemen Strategik. Jakarta: PT. Pustaka Binaman Pressindo.

Rahim, Husni.2002.Pendidikan Islam Di Indonesia Keluar Dari Eksklusivisme, (dalam Pendidikan untuk masyarakat Indonesia baru). Ikhwanuddin dan Dodo Murtadlo (editor). Jakarta: PT Grasindo.

Ratminto dan Atik Septi Winarsih. 2005. Manajemen Pelayanan. Yogyakarta: Pustaka Pelajar.

Robbins, Stephen P. 1983. Organizational Theory: The Structure and Desing of Organizations. Englewood Cliffs. NJ: Prentice-Hall.

. 2001. Perilaku Organisasi: Konsep, Kontroversi, Aplikasi, Jlid ke-2 Edisi Bahasa Indonesia. Jakarta: Prenhallindo.

Robert G. Owens. 1995. Organizational Behavior in Education. Boston: Allyn and Bacon.

Salfen Hasri. 2004. Manajemen Pendidikan: Pendekatan Nilai dan Budaya Organisasi. Makassar: Yayasan Pendidikan Makassar.

Sallis, E. 1993. Total Quality Management in Education. London: Kogan Page Limited. 
Schultz, T.W. 1961. Invesment in Human Capital. The American Economics Review, No. 51, March 1961.

Seattle Public School, Washington. 1982. Effective School Seminar Report. Albany: ERIC, Albany.

Shaum Tyson \& Tony Jackson. 2001. Organizational Behaviour. Perilaku Organisasi (terj). Yogyakarta: Penerbit Andi.

Siagian, Sondang P. 1985. Manajemen SDM. Jakarta:PT. Grafika offset 1994. Analisis serta Perumusan Kebijaksanaan dan Strategi Organisasi. Jakarta: CV. Haji Masagung.

Sinamo, H.J. 1998. Menciptakan Visi Motivatif (In Search of Powerful Vision). Jakarta: Majalah Manajemen, Agustus.

Snyder, Karolyn J, Anderson, Robert H. 1986: Managing Productive School, Toward An Ecology. Florida: Hartourt Brace Javanovich, Publishers, Orlanda.

Sonhadji, Akhmad. 2004. Visi Madrasah Aliyah Model: Populis, Islami, dan Berkualitas. Makalah, tidak dipublikasikan.

Sugiyono. 2005. Memahami Penelitian Kualitatif. Bandung: CV.Alfabeta.

. 2006. Metode Penelitian Pendidikan. Bandung: CV.Alfabeta.

Sunarto dan Sahedhy Noor SK. 2001. Manajemen Sumber Daya Manusia. Yogyakarta: BPFE UST.

Trimo. Soejono. 1990. Perencanaan Strategi Salah Satu Dimensi Dalam Proses Pengambilan Keputusan. Bandung: Angkasa.

Umedi. 2004. Manajemen Mutu Berbasis Sekolab/Madrasah (MMDS/M). Jakarta: Pusat Kajian Manajemen Mutu Pendidikan. 
Undang-Undang Republik Indonesia. Nomor 20 tahun 2003. tentang Sistem Pendidikan Nasional . Nomor 14 Tahun 2005. tentang Guru dan Dosen

Wahjosumidjo. 2005. Kepemimpinan Kepala Sekolab: Tinjauan Teoritik dan Permasalahannya. Ed.1. Jakarta: PT. Raja Grafindo Persada. 